Jurnal ECOTIPE, Volume 7, No.1, April 2020, Hal. 7-11

p-ISSN 2355-5068, e-ISSN 2622-4852

Akreditasi Kemenristekdikti (SINTA 4), SK. No.10/E/KPT/2019

DOI: $10.33019 /$ ecotipe.v7i1.1388

\title{
Simulation of Turbines Design For Hidropower In Way Laai and Way Lami Pesisir Barat District, Lampung Province
}

\author{
Kiki Kananda, Dean Corio, Efa Maydhona S. \\ Electrical Engineering Department, Institut Teknologi Sumatera, Lampung Selatan, Lampung \\ kiki.kananda@el.itera.ac.id
}

\begin{abstract}
Hydropower is considered to be one of important renewable energy sources. Renewable energy is the second-largest contributor to global electricity production after fossil fuel. Hydropower generation presents several advantages over most other sources of electrical power. It includes a high level of reliability, proven technology, high efficiency (about $90 \%$ ), very low operating and maintenance costs, flexibility and large storage capacity. Based on the types of installation, hydropower can be categorized as; impoundment, diversion, and pump storage, and based on the turbine types can it be classified as reaction and impulse systems. Previous research gives the results of the initial survey, concluding that there are two rivers that have the potential to become a micro or mini-hydro generator that has biggest mechanical power; Way Laai and Way Lami. So, in further research it is necessary to analyze the type of turbine suitable for both rivers as part of the process of developing a micro hydropower. We use analytical methods through TURBNPRO simulation software to assist in designing Turbines that are in accordance with the standards and designs used by manufacturers in general. The simulation result gives one alternative to the right turbine design for Way Laai is the orientation vertical of 6 jet Pelton with a peak efficiency of 89.9\%. The right alternative turbine design for Way Lami is the vertical orientation Axial turbine/ propeller design with a peak efficiency of $93.3 \%$.
\end{abstract}

Keywords : Hydropower, Microhydro, Renewable Energy, Turbines

\section{INTISARI}

Pembangkit tenaga air dianggap sebagai salah satu sumber energi terbarukan yang penting. Energi terbarukan adalah kontributor terbesar kedua untuk produksi listrik global setelah bahan bakar fosil. Pembangkit listrik tenaga air menghadirkan beberapa keunggulan dibandingkan sebagian besar sumber tenaga listrik lainnya. Ini termasuk tingkat keandalan yang tinggi, teknologi terbukti, efisiensi tinggi (sekitar 90\%), biaya operasi dan pemeliharaan yang sangat rendah, fleksibilitas dan kapasitas penyimpanan yang besar. Berdasarkan jenis instalasi, tenaga air dapat dikategorikan sebagai: penampung, pengalihan, dan penyimpanan pompa, dan berdasarkan jenis turbin dapat diklasifikasikan sebagai sistem reaksi dan impuls. Penelitian sebelumnya memberikan hasil survei awal, menyimpulkan bahwa ada dua sungai yang berpotensi menjadi pembangkit mikro atau minihydro yang memiliki daya luaran mekanik terbesar; Way Laai dan Way Lami. Jadi, pada penelitian lanjutan perlu menganalisis jenis turbin yang cocok untuk kedua sungai tersebut sebagai bagian dari proses pengembangan pembangkit mikro hydro. Kami menggunakan metode analisis melalui simulasi perangkat lunak TURBNPRO untuk membantu dalam mendesain Turbin yang sesuai dengan standarisasi dan rancangan yang digunakan produsen pada umumnya. Hasil simulasi memberikan satu alternatif untuk desain turbin yang tepat untuk Way Laai adalah Pelton 6 jet orientasi vertikal dengan efisiensi puncak $89,9 \%$. Desain turbin alternatif yang tepat untuk Way Lami adalah orientasi vertikal Desain turbin / baling-baling aksial dengan efisiensi puncak $93,3 \%$.

Kata kunci: Pembangkit Tenaga Air, Mikrohidro, Energi Terbarukan, Turbin

\section{Introduction}

Hydropower generation is the most issue in electricity world. Hydropower is considered to be one of important renewable energy sources. Renewable energy are the second largest contributor to the global electricity production after fossil fuel [1]. Hydro power generation presents several advantages over most other sources of electrical power. It is include a high level of reliability, proven technology, high efficiency (about 90\%), very low operating and 
Jurnal ECOTIPE, Volume 7, No.1, April 2020, Hal. 7-11

p-ISSN 2355-5068, e-ISSN 2622-4852

Akreditasi Kemenristekdikti (SINTA 4), SK. No.10/E/KPT/2019

DOI: 10.33019/ecotipe.v7i1.1388

maintenance costs, flexibility and large storage capacity [2].

Hydropower can be classified as: pico $(<$ $5 \mathrm{~kW})$, micro $(5 \mathrm{~kW}-100 \mathrm{~kW})$, small $(101 \mathrm{~kW}-$ $2000 \mathrm{~kW})$, mini (2001kW - $25000 \mathrm{~kW})$, and large $(>25000 \mathrm{~kW})$ [1][3]. Based on the types of installation, hydropower can be categorized as: impoundment, diversion, and pump storage, and based on the turbine types can it be classified as reaction and impulse systems[1]. The Pelton and Turgo turbines are classified as impulse turbines. The Cross Flow, Kaplan and Francis are reaction turbines. In rural and remote areas in micro-hydro powerplants that use a lot of cross-flow turbines are urgently needed [4].

Previous research [3] give the results of the initial survey, concluding that there are two rivers that have the potential to become a micro or minihydro generator that has biggest mechanical power; Way Laai and Way Lami. The maximum design discharge of Way Laai of $4.52 \mathrm{~m}^{3} / \mathrm{s}$ can produce a mechanical output power of 1223.82 $\mathrm{kW}$ with an effective head of $44.16 \mathrm{~m}$. Way Lami with a design discharge of $5,336 \mathrm{~m}^{3} / \mathrm{s}$, an effective head of $28.8 \mathrm{~m}$ has the potential to provide a mechanical power output of $942.23 \mathrm{~kW}$. Now, for further reasearch we need to know what is turbines type suit the both rivers as part of developing a micro hyrdopower. We used simulation methode, same method with other research [5] that used TURBNPRO simulation software to assist in designing Turbines that are in accordance with the standards and designs used by manufacturers in general.

\section{Result and Discuss}

The TURBNPRO software was chosen as an aid to accelerate the selection of turbine types that are in accordance with the standards and design of producers available in the market, making it easier to provide for further development. This software provides a turbine design that is accurate and good enough in providing turbine details that are in accordance with the standardization and designer of the manufacturer, does not examine the economic side but rather on evaluating the effectiveness and efficiency of turbine design. This software is also free so this is an additional choice for used it. In using this software, we need some data available as a basis for calculating the type of turbine recommended by the simulation results.

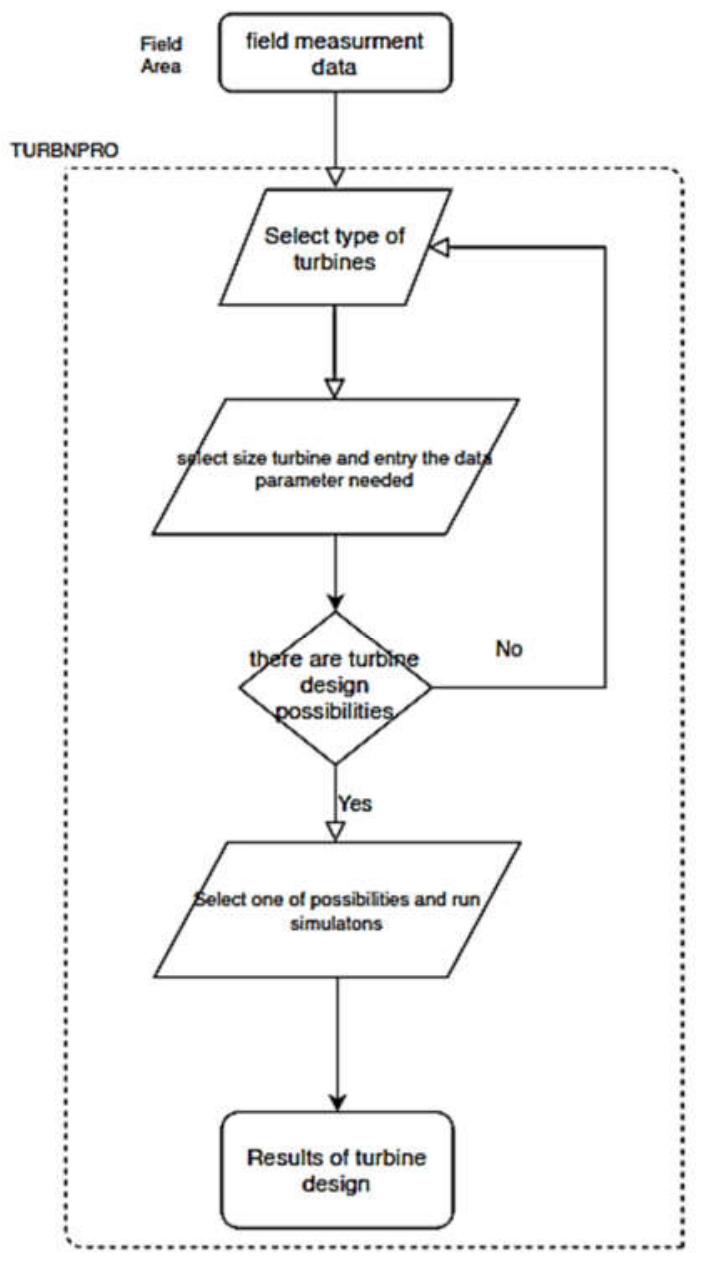

Fig.1. How to Get Turbine Design

For turbine calculations, we need some data related to design discharge and effective head for both rivers. For the Way Laai river, 2 calculations are used for the right way with minimum discharge and the Way Laai which is the maximum discharge (Right-Left). The turbine design calculation is done with the help of TURBNPRO software (Figure 1). Based on the calculation of the 
Jurnal ECOTIPE, Volume 7, No.1, April 2020, Hal. 7-11

p-ISSN 2355-5068, e-ISSN 2622-4852

Akreditasi Kemenristekdikti (SINTA 4), SK. No.10/E/KPT/2019

DOI: 10.33019/ecotipe.v7i1.1388

measured power [3], the river flow with the head and discharge is categorized in the medium head, so the turbine design will be calculated with the Pelton and Axial Propeller turbine design.

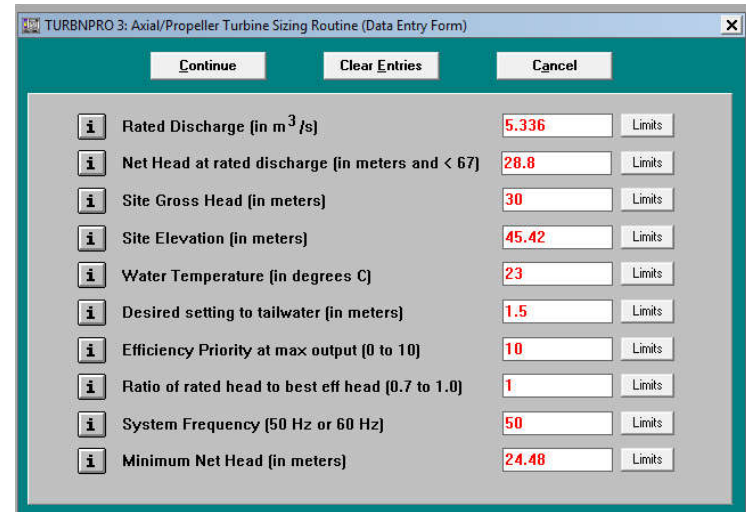

Fig.2. Data Entry Turbin Axial/Propeller Way Lami

Both Way Laai and Way Lami used the initial data entry, such as (Figure 2); Rate discharges, $\mathrm{max} / \mathrm{mim} / \mathrm{net}$ head, water temperatures, efficiency priority, and sysem frequency. After used the TURBNPRO, Way Laai with $46 \mathrm{~m}$ head gross included in medium head, so the Pelton type was chosen. The result give Pelton Turbines with number jet 4 and runner diameter less than 1515 $\mathrm{mm}$. Chosen turbine for Way Laai give peak efficiency $89.9 \%$ and speed $176.5 \mathrm{rpm}$ and it will be increased each $10 \%$ to $80 \%$ and then each $1 \%$ furthermore.

Way Lami with $30 \mathrm{~m}$ gross head, $<40 \mathrm{~m}$ included in the low head, so the Axial propeller type was chosen. In this type of turbine the temperature value of $23^{\circ} \mathrm{C}$ is taken with the estimated normal river temperature.

Figure 3 described the turbines solution possibilities from TURBNPRO for Way Lami. There are two choices which can be chosen and we get number 2. For this turbine, regulations with Adjustable Gate and fixed Blade are chosen to make it easier to regulate and maintain. The solution summary in detail specifications can see Figure 4.

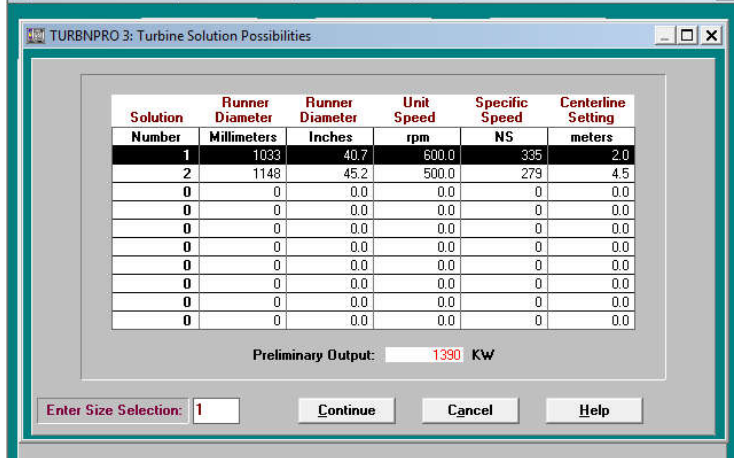

Fig.3. Solution of Tubines Axial/Propeller Way Lami with Centerline Setting $2 \mathrm{~m}$

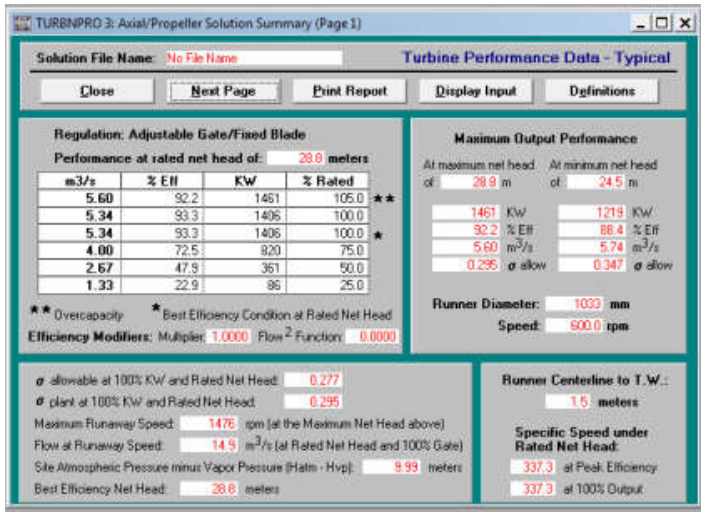

Fig. 4. Turbines specifications Axial/Propeller Way Lami

The typical dimensions of Turbines Axial/Propeller show in Figure 5 below.

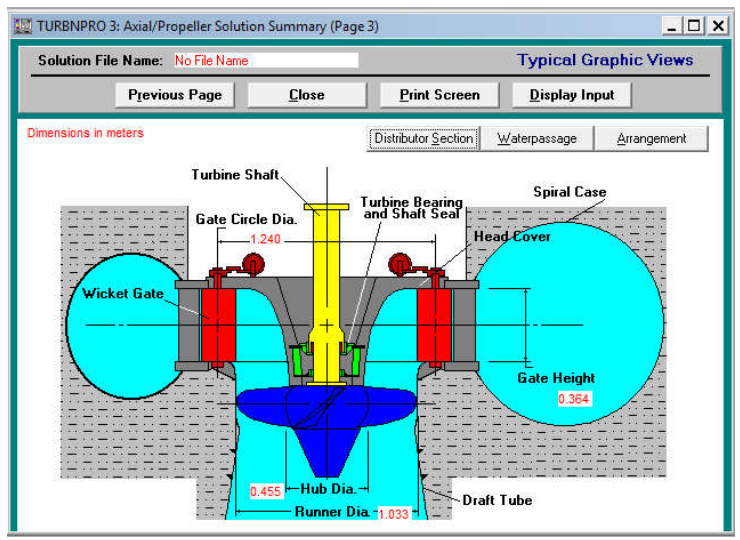

(a) 
Jurnal ECOTIPE, Volume 7, No.1, April 2020, Hal. 7-11

p-ISSN 2355-5068, e-ISSN 2622-4852

Akreditasi Kemenristekdikti (SINTA 4), SK. No.10/E/KPT/2019

DOI: $10.33019 /$ ecotipe.v7i1.1388

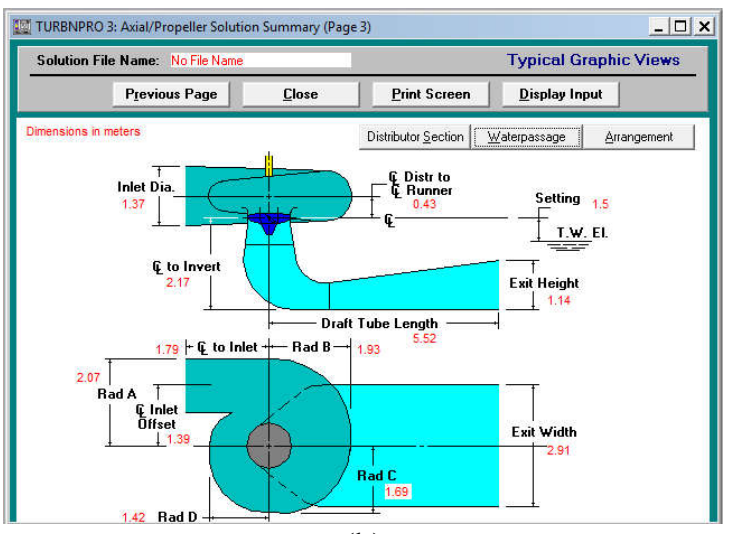

(b)

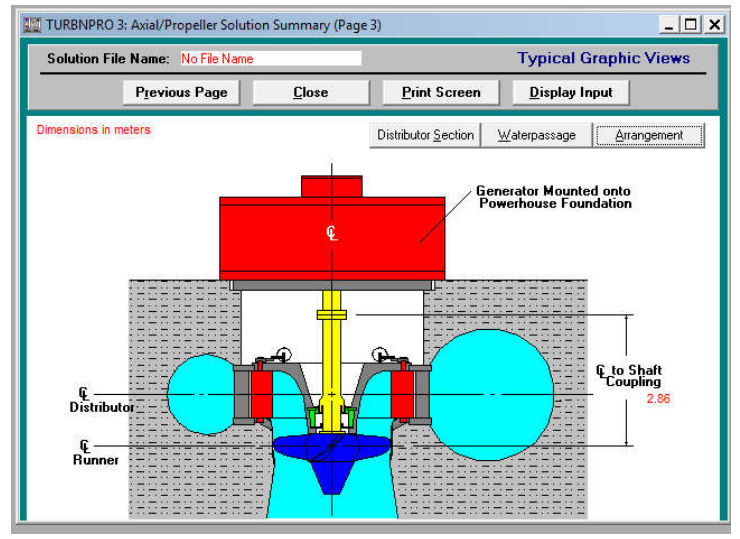

(c)

Fig.5. Turbines Detail Specifications Axial/Propeller Way Lami (a)Distributor Section

(b)Waterpassage (c) Arrangement

The performance characteristics of turbines designed for various effective and discharge heads are depicted on a "hill curve " with efficiency lines ( show in graph Figure 6). For Way Lami Turbines the highest efficiency for turbines is $93.3 \%$. The efficiency line stays from the $0 \%$ efficiency (the horizontal line closest to the bottom of the graph) and increases every $10 \%$ to an efficiency of $80 \%$. From an efficiency of $85 \%$ to the top the efficiency line increases every $5 \%$. The results of the software simulation design using TURBNPRO cannot be fully implemented directly, because for its implementation and development, further studies are needed, such as financial/ economic feasibility, physical development and power flow study. But, its can be used as a basis for selecting turbines in the market according to the standardization and design of the manufacturer in general.

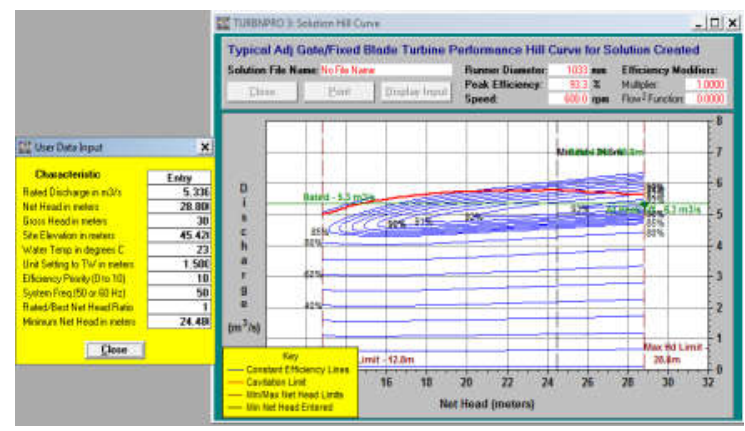

Fig.6. Performance Turbin Axial/Propeller Way Lami

\section{Conclusions}

This simulation of design turbines as a base for selecting turbines in the market according to the standardization and design of the manufacturer in general, that give:

a. The maximum design discharge Way Laai of $4.52 \mathrm{~m}^{3} / \mathrm{s}$ can produce $1223.82 \mathrm{~kW}$ mechanical output power with an effective head of $44.16 \mathrm{~m}$

b. Way Lami with a design discharge of 5.336 $\mathrm{m}^{3} / \mathrm{s}$, an effective head of $28.8 \mathrm{~m}$ has the potential to provide a mechanical power output of $942.23 \mathrm{~kW}$.

c. One alternative to the right turbine design for Way Laai is the orientation vertical of 6 jet Pelton with a peak efficiency of $89.9 \%$.

d. The right alternative turbine design for Way Lami is the vertical orientation Axial turbine/ propeller design with a peak efficiency of 93.3\%.

e. Further studies are needed, such as financial/ economic feasibility, physical development and power flow study of hydropower.

\section{Acknowledgements}

The authors would like thank to Institut Teknologi Sumatera for the financial support by BOPTN 
Jurnal ECOTIPE, Volume 7, No.1, April 2020, Hal. 7-11

p-ISSN 2355-5068, e-ISSN 2622-4852

Akreditasi Kemenristekdikti (SINTA 4), SK. No.10/E/KPT/2019

DOI: 10.33019/ecotipe.v7i1.1388

funding through institute competitive research in 2018 (No. 134an/IT9.C1/PP/2018)

\section{REFERENCES}

[1] Casini, Marco. 2015. Harvesting energy from in-pipe hydro systems at urban and building scale International Journal of Smart Grid and Clean Energy, vol. 4, no. 4, October 2015

[2] Nababan, Sabar., E. Muljadi, F. Blaabjerg. 2012. An Overview of Power Topologies for Micro-hydro Turbines. 3rd IEEE International Symposium on Power Electronics for Distributed Generation Systems (PEDG) 2012, 978-1-4673-2023-8/12/\$31.00/ (C2012 IEEE

[3] Kananda, Kiki.,Corio, Dean., etc. 2018. Potential Analysis of Hydro Power Plants in Pesisir Barat District, Lampung Province. ICOSITER 2018 Proceeding-Journal of Science and Applicative Technology

[4] Rantererung, Corvis L., Soeparman, Sudjito., Soenoko, Rudy., Wahyudi, Slamet. 2016. Dual Nozzle Cross-Flow Turbine as an Electrical Power Generation. ARPN Journal of Engineering and Applied Sciences. Vol. 11, No. 1, January 2016

[5] Jamali, Firman. _. Planning Study of Minihodro Power Projects Supported by Turbinpro Program in Sinar Pekayau Village, Sepauk District, Sintang District. Electrical Engineering Study Program, Faculty of Engineering, University of Tanjungpura 